Красинский Владислав Вячеславович кандидат юридических наук

Источник опубликования: Красинский В.В. Идеология восстания в истории политико-правовых учений // Политика и общество. 2005. № 6. С. 19-29; www.krasinskiy.ru

\title{
ИДЕОЛОГИЯ ВОССТАНИЯ В ИСТОРИИ ПОЛИТИКО- ПРАВОВЫХ УЧЕНИЙ
}

Во все времена и практически в любом классово-организованном обществе существовали и существуют люди, недовольные социальноэкономическим положением в стране, государственно-политическим режимом, господствующей идеологией, законодательством, претендующие на роль «защитников народа» и предлагающие пути ускоренного построения более справедливого общества и государства.

Основная пропагандируемая ими идея заключается в том, что существующая политическая власть угнетает народ, поэтому во имя грядущего прогрессивного общественного строя и социальных преобразований эта власть должна быть насильственно ликвидирована. Носители таких радикальных идей призывают своих сторонников к совершению революций, переворотов, народных восстаний. С чем же связана историческая «живучесть» подобных взглядов «идеологов восстания»? Как эти и похожие на них идеи формировались в общественном сознании? Какова современная трактовка права народа на восстание?

Приступая к разработке предмета исследования, определимся с терминологией. Для этого проанализируем соотношение понятий «революция», «переворот» и «восстание», а также раскроем смысловое значение «идеологии восстания».

В западной юридической и социологической литературе революция отождествляется с «быстрыми, неожиданными изменениями в социальной структуре или же в наиболее важных ее частях» (Уэйд Р., Скоцпол Т.). 
В отечественной науке под революцией традиционно понимают «коренной переворот в жизни общества, означающий низвержение отжившего и утверждение нового, прогрессивного общественного строя», «форму перехода от одной общественно-экономической формации к другой» ${ }^{1}$. Как справедливо отмечает Марченко М.Н., «в государственноправовой теории и политической практике революция, олицетворяющая собой смену типов государства и права, переход власти от одного правящего класса к другому, нередко подменяется переворотом. Последний означает антиконституционный, чаще всего насильственный переход (захват) власти от одной части правящего класса к другой, от одной группы или фракции господствующей политической элиты к другой. Переворот, независимо от его названия (военный, государственный, дворцовый) не влечет за собой непосредственно смену типа или типов государства... Переворот влечет за собой лишь частичные, нередко поверхностные изменения в государственном механизме и его деятельности (изменения формы правления, политического или государственного режима, ряда направлений внутренней и внешней политики)»².

В ходе революции осуществляется переход государственной власти в руки нового класса. Этот переход совершается насильственным путем (вооруженное восстание или гражданская война) или относительно мирно 3 .

В настоящей статье мы рассматриваем восстание как насильственный способ завоевания политической власти, целью которого является смена исторического типа государства. С учетом этого, под идеологией восстания понимается система политико-правовых, нравственных, религиозных, философских идей и взглядов, выражающих интересы определенных классов

${ }^{1}$ См.: Большая советская энциклопедия. М.: Советская энциклопедия, 1975. Т. 21. С. 545; Советский энциклопедический словарь. М.: Советская энциклопедия, 1981. С. 1121; Великая Октябрьская социалистическая революция: энциклопедия / Под ред. П.А. Голуба, Ю.И. Кораблева и др. М.: Советская энциклопедия, 1987. С. 494; Философский словарь / Под ред. И.Т. Фролова. М.: Политиздат, 1991. С. 386 и др.

${ }^{2}$ См.: Общая теория государства и права. Академический курс в 2-х томах / Под ред. М.Н. Марченко. Т.1. М.: Изд-во Зерцало, 1998. С. 107-108.

${ }^{3}$ В качестве разновидностей вооруженного восстания выделяют бунт - стихийное, неорганизованное выступление масс, без четко осознанной цели, и путч - подготовленное офицерское выступление с целью установления военной диктатуры. 
или социальных групп и обосновывающих необходимость насильственной смены исторического типа конкретного государства. Основополагающим ядром идеологии восстания является та или иная теоретическая аргументация права народа на восстание.

Идеология восстания в истории политических и правовых учений сыграла весьма прогрессивную роль. В эпоху Средневековья она была составной частью радикальных программ Реформации (Т. Мюнцер, Ж. Кальвин, гуситское революционное движение), которые способствовали демократизации церкви и повлияли в дальнейшем на формирование буржуазного мировоззрения. В период буржуазных революций именно идеология восстания определяла прогрессивное развитие и демократизацию общественных отношений. Право на восстание было основополагающим в ходе Войны за независимость в США. В XX в. данная идеология во многом предопределила ликвидацию мировой колониальной системы.

Идеология восстания оформлялась постепенно, в борьбе с представителями иных философских, политических, религиозных взглядов на переустройство общества. На протяжении всего развития политикоправовых учений существовали мыслители, которые выступали за беспрекословное подчинение властям при любых условиях, и их оппоненты, которые являлись сторонниками права на восстание.

Наиболее известным противником народных восстаний являлся классик мировой философской и политической мысли Иммануил Кант.

Кант категорически отвергал право на восстание. Он полагал, что надо повиноваться ныне существующей власти, каково бы ни было ее происхождение.

«Против законодательствующего главы государства нет правомерного сопротивления народа, ведь правовое состояние возможно лишь через подчинение его устанавливающей всеобщие законы воле, следовательно, нет никакого права на возмущение, еще в меньшей степени - на восстание и в наименьшей степени - права посягать на его особу как единичного лица 
(монарха) и на его жизнь под предлогом, что он злоупотребляет своей властью (tyrannis). Малейшая попытка в этом направлении составляет государственную измену, и такого рода изменник может караться только смертной казнью как за попытку погубить свое отечество» ${ }^{4}$.

В силу схожих идеологических установок отвергали революционный путь развития консерваторы и значительная часть либералов. Отрицательное отношение к насильственной революции объединяет и идеологов социалдемократии.

Большой интерес представляют возникшие в противовес радикальнореволюционным идеям и апробированные в $\mathrm{XX}$ в. концепции ненасильственного сопротивления, сформулированные Львом Николаевичем Толстым, Мохандасом Ганди и Мартином Лютером Кингом.

Лев Николаевич Толстой выдвинул основанную на христианских заповедях концепцию непротивления злу насилием. Насильственной революционной деятельности Толстой противопоставил «истину об агнце», который добром и смирением победит всех: «Не сердитесь, не прелюбодействуйте, терпите зло, любите врагов... Если бы все так жили, и не нужно бы и революции» ${ }^{5}$. Единственными средствами борьбы со злом Толстой считал его публичное обличение и пассивное неповиновение властям.

Родственное идеям Толстого социально-политическое и религиознофилософское учение Мохандаса Карамчанда Ганди отрицало возможность революционного преобразования общества и проповедовало тактику ненасильственной национально-освободительной борьбы в Индии (сатьяграха) в двух формах: несотрудничества и гражданского неповиновения 6 .

${ }^{4}$ См.: Кант И. Метафизика нравов / Соч. в 6 тт. Т.4. Ч. 2. М., 1965. С. 107-304.

${ }^{5}$ См.: Толстой Л.Н.. Божеское и человеческое / Собр. соч. в 12 томах. Т. 11. С. 465, 487.

${ }^{6}$ Кампании несотрудничества (бойкот учебных заведений, мирные демонстрации) и гражданского неповиновения (политические забастовки, свертывание деловой активности, отказ от уплаты налогов) были развернуты в Индии в 1919-1922 гг., в 1929-1933 гг. 
Аналогичным образом следует оценивать и политическую доктрину борца за права негров в США Мартина Лютера Кинга, фундаментом которой является тактика ненасильственных действий.

Значение указанных концепций ненасильственного сопротивления заключается в том, что они составили серьезную альтернативу идеологии восстания, приобрели во многих странах и среди различных социальных групп массу сторонников и вытеснили революционно-радикальные взгляды из области господствующего общественного сознания.

Несмотря на утрату прежнего влияния на общественное развитие, идеология восстания продолжает занимать определенное место в социальных и политических преобразованиях, имеет собственную социальную базу и периодически «реанимируется» к жизни политическими лидерами в отдельных странах мира. Живучесть идей, обосновывающих необходимость насильственной смены исторического типа государства, вызвана их простотой, доступностью, глубокой теоретической проработкой и углублением острых социально-экономических и политических противоречий, присущих в настоящее время для большинства стран т.н. «третьего мира».

Идеологическое обоснование права на восстание имеет глубокие исторические корни.

Среди множества учений сторонников права на восстание можно выделить:

- различное обоснование права на восстание (религиозное, светское);

- различные подходы к целям восстания (захват государственной власти другим классом, преобразование общественных отношений, восстановление утраченного государственного суверенитета);

- различное видение субъектов права на восстание (представительные органы, церковь, народ и др.); 
- различные подходы к средствам осуществления восстания (применение насилия в отношении представителей власти или необходимость ограничения подобных действий);

- наличие (отсутствие) продуманной тактики восстания.

Своеобразием отличаются взгляды мыслителей-богословов, предлагавших религиозное обоснование права на восстание.

Так, Фома Аквинский полагал, что если действия правителя отклоняются от воли Божьей, то они противоречат интересам церкви и подданные вправе оказывать этим действиям сопротивление. Неповиновение является правомерным в двух случаях:

- когда повелевается то, что противно повелению Божьему;

- когда повелевается то, на что не простирается власть правителя (например, на духовную жизнь людей).

Народ может восстать и свергнуть правителя, что не является смертельным грехом. Кроме того, Фома Аквинский допускал и тираноубийство, которое должно совершаться по решению общества. Главное, по мнению Аквинского, чтобы восстание приносило больше пользы, чем вреда. Можно сказать, что Аквинский проводил определенную аналогию между восстанием и крайней необходимостью: вред, причиненный в состоянии крайней необходимости, должен быть менее значительным, чем вред предотвращаемый. Ограниченность предложенной Аквинским теологической аргументации права народа на восстание заключается в том, что интересы восставших вытекают из Божьего повеления и отождествляются с интересами церкви. На самом деле восставшие стремились и стремятся к реализации в первую очередь близких им интересов. Другое дело, что церковь в эпоху Средневековья активно участвовала в борьбе за государственную власть и нередко поддерживала выгодные ей народные восстания ${ }^{7}$.

\footnotetext{
${ }^{7}$ Католическая церковь в тот период не раз обращалась к подданным с призывом не повиноваться тому или иному неугодному ей правителю.
} 
Дальнейшее развитие идеология восстания получила в эпоху Реформации.

Основатель кальвинистской церкви Жан Кальвин полагал, что насилие, произвол и беззаконие власти покарает Бог. Обязанность государей - не отягощать налогами иначе как для удовлетворения общественных нужд, и не покрывать притеснителей народа (отсюда вытекают предпосылки для обострения социальной напряженности: недовольство населения своим социально-экономическим положением в результате обременительной налоговой политики и отсутствие социальной справедливости). Кальвин признавал право на сопротивление тирании и выделял перечень субъектов, обладающих исключительным правом на восстание: органы власти, церковь и представительные учреждения. Кальвин подчеркивал исключительный характер права народа на восстание. Вооруженное неповиновение и свержение тирана, по мнению Кальвина, возможны лишь в том случае, когда исчерпаны все законные формы сопротивления.

После Варфоломеевской ночи среди французских кальвинистов (гугенотов) получили распространение произведения монархомахов (И. Жантийе, Ла Боэси и др.). В центре внимания монархомахов стояли проблемы соотнесения государя и тирана и допустимости борьбы с тиранами.

И. Жантийе в трактате «Анти-Макиавелли» называет борьбу с тираном обязанностью граждан.

В трактате «Рассуждение о добровольном рабстве» (ок. 1548) Этьен де Ла Боэси выступает против тирании с позиций естественного равенства людей и критикует абсолютистский режим власти, характеризующийся отсутствием законности и гарантий прав личности. По мнению Ла Боэси, тирания, возникнув в силу разных причин (сила, наследование, договор), 
удерживается только привычкой народа к рабству. Народ терпит злодеяния тирана добровольно, вследствие привычного заблуждения ${ }^{8}$.

Победа антифеодальных революций в Нидерландах и Англии способствовала формированию новой политико-правовой идеологии, в основе которой лежала теория естественного права. По мере развития естественно-правовой теории менялась и аргументация права на восстание.

Так, по мнению голландского мыслителя Гуго Гроция, народ может избрать любую форму правления. Главное, чтобы в рамках этой формы правления осуществлялась воля людей. Избрав форму правления, народ должен повиноваться правителям, поскольку договоры должны исполняться. Тем не менее Гроций допускает право народа на восстание в следующих случаях:

Если такое право (явно или неявно) следует из общественного договора;

Если сам общественный договор расторгнут или грубо нарушен правителями государства;

Если правитель, проникнутый враждебным духом, замышляет гибель всего народа;

Если имеет место захват власти путем неправой войны.

Право народа на восстание в теории Гроция включает не только сопротивление властям силой, но и наказание правителей смертью.

Другой теоретик естественно-правовой теории Бенедикт Спиноза обосновывает право на восстание посредством концепции «пределов права государства».

Во-первых, эти пределы устанавливаются требованиями разума, который воплощается в законах.

Во-вторых, предел права государства обусловлен природой подданных. К праву государства не может относиться то, к чему государство не в состоянии побудить подданных наградами или наказаниями (влиять на 1962

${ }^{8}$ Подробнее см.: Этьен Ла Боэси. Рассуждение о добровольном рабстве. М.: Наука, 
способность людей думать, любить, верить в Бога, защищать свою жизнь). Другими словами, это естественные неотчуждаемые права человека.

В-третьих, к праву государства не относится то, на что негодует большинство, «...мощь и право государства уменьшаются постольку, поскольку оно само дает поводы значительному числу лиц к заговору». Государственная власть не должна совершать действий, подрывающих ее авторитет или вызывающих негодование подданных. В этом ракурсе Спиноза связывает право народа на восстание с легитимностью власти.

Спиноза считал, что нарушение законов властями ведет к тому, что общий страх большинства граждан превращается в негодование против властей, при этом «разрушается государство и прекращается договор». Таким образом, Спиноза признает естественное право на восстание в случае нарушения государственными властями условий общественного договора.

Схожих взглядов придерживался и основоположник либерализма Джон Локк. На взгляд Локка, длительные злоупотребления и хитрости со стороны власти дают народу право на восстание. Вопрос в том, что именно считать «длительными» злоупотреблениями.

Предвестник французских просветителей коммунист Жан Мелье в своем «Завещании» призывал народ к объединению и созданию тайной организации для революционной борьбы против тиранов и религии: «Надо по примеру древних римлян, объединившись, истреблять и убивать тиранов, сделать их в своих писаниях предметом ненависти и презрения в глазах всего света и поднять все народы на то, чтобы стряхнуть с себя невыносимое иго их тиранического владычества» ${ }^{9}$.

Значительное влияние на общественное сознание и дальнейшее развитие идеологии восстания оказала политико-правовая доктрина Жана-Жака Pycco.

В главе III трактата «Об общественном договоре» Руссо выдвинул тезис о необходимости повиновения только законным властям: «Всякая власть

${ }^{9}$ См.: Мелье Ж. Завещание. М.: Государственное антирелигиозное издательство, 1937. C. 379. 
происходит от Бога; согласен; но и всякая болезнь тоже происходит от Бога; но разве это значит, что нельзя позвать врача?.. Согласимся же, что сила не создает права, и что человек обязан повиноваться только законным властям» ${ }^{10}$.

В работе «Рассуждения о происхождении и основаниях неравенства между людьми» французский мыслитель поставил проблему пределов народного суверенитета и разрешил ее с позиций права народа на восстание против деспота: «...Восстание, которое приводит к убийству или свержению с престола какого-нибудь султана, это акт столь же закономерный, как и те акты, посредством которых он только что распоряжался жизнью и имуществом своих подданных. Одной только силой он держался, одна только сила его и низвергает...»

В отличие от своих предшественников, допускающих в качестве исключения возможность сопротивления властям, Руссо обосновал правомерность и необходимость насильственного свержения деспотического строя и явился основоположником нового направления общественной мысли - политического радикализма.

Политико-правовое учение Руссо было практически воплощено и теоретически переработано якобинцами и бабувистами ${ }^{11}$.

Характерной особенностью якобинцев было их учение о восстании и революционной диктатуре. В работе «Цепи рабства» один из якобинских вождей Жан Поль Марат развил идею неприемлемости деспотического абсолютизма, исследовал истоки, методы и средства установления деспотического политического режима, негативные последствия деспотизма, рассмотрел восстание как эффективный способ борьбы с ним. Марат выступает за революционную диктатуру с целью уничтожения заговорщиков

10 См.: Руссо Жан-Жак. Об общественном договоре или основные начала государственного права. СпБ.: Издание Д.Е. Жуковского, 1907. С. 11-12.

${ }_{11}$ В результате восстания 31 мая - 2 июня 1793 г. во Франции была установлена якобинская революционная диктатура. Конвент принял Конституцию 1793 г., в которой нашли отражение идеи Ж.-Ж. Руссо, в частности, право на сопротивление угнетению. 
и врагов революции. Он допускает целесообразность применения революционного террора к врагам общества ${ }^{12}$.

Максимилиан Робеспьер обосновывал идею верховенства народной власти в государстве и концепцию революционного правительства. «Если один из членов общества подвергается угнетению, то налицо угнетение каждого члена общества. Право на сопротивление угнетению есть следствие из других прав человека». Революционное правительство, наделенное чрезвычайными полномочиями, должно реализовать это право.

У Гракха Бабефа революционная диктатура выступала рычагом грядущего переворота, после которого начнется освобождение трудящихся и строительство коммунизма.

Тактика восстания изложена Бабефом в программном документе «Акт восстания»:

«Рано утром в предместьях Парижа начнет бить набат. Агенты Повстанческого комитета обнародуют акт восстания и приведут свои отряды... Когда таким образом сформируется народная армия, она, поддержанная всем рабочим классом столицы, двинется к Законодательному корпусу, к Исполнительной Директории и к штабу внутренней армии. Наилучшие вооруженные граждане должны будут захватить склады оружия. Будут также заняты национальное казначейство, почта, дома министров и все общественные и частные магазины с жизненными припасами и военным снаряжением. На случай временной заминки приняты меры к заграждению улиц. Правительственные войска будут облиты водой, смешанной с купоросом, засыпаны градом камней и черепиц. После достижения окончательной победы повстанцы обратятся к народу с воззванием, разъясняющим смысл и значение происшедшей революции. Всякое сопротивление будет жестоко караться...» ${ }^{13}$. Акты восстания и все другие акты, подлежащие опубликованию в этот день, будут подписаны

12 В 1793 г. комиссары Конвента развернули массовый кровавый террор против политической и экономической контрреволюции.

${ }^{13}$ См.: Щеголев П. Гракх-Бабеф. М., 1933. 
Повстанческим комитетом общественного спасения, который станет революционным правительством.

Значение политико-правового учения Бабефа заключается в том, что он развил якобинскую концепцию временного революционного правительства и предложил свое видение ликвидации сословно-феодального строя.

Под воздействием просветительской философии и бабувизма сформировалось мировоззрение французского утопического коммуниста Луи Огюста Бланки.

Бланки был сторонником социальной революции. Ее успех он связывал с хорошо подготовленным заговором тайной революционной организации, которую в решающий момент должен поддержать народ. Выдвинутая Бланки тактика заговоров страдала ограниченностью и подвергалась обоснованной критике, поскольку успешное восстание назревает закономерно и возможно лишь при активном участии в нем народа.

Радикальные идеи европейских просветителей распространялись не только в Европе, но и далеко за ее пределами. Как уже отмечалось, идеология восстания, сформулированная просветителями, оказала заметное влияние на освобождение США от колониального владычества Великобритании в ходе Войны за Независимость. Основные идеи освободительного движения были выдвинуты «отцами-основателями» Бенджамином Франклином, Томасом Пейном и Томасом Джефферсоном и закреплены в Декларации Независимости 1776 г.

«Отцы основатели» США единодушно отстаивали право народа на революцию. Они полагали, что существование власти зависит только от согласия управляемых. При этом Джефферсон делал еще более радикальные выводы о том, что идеи восстания являются частью общественного сознания и органично включены в систему ценностей американской демократии. Правители должны получать время от времени предупреждения о том, что народ сохраняет свой дух сопротивления. «Дерево свободы необходимо 
поливать время от времени кровью тиранов и патриотов. Это его естественное удобрение».

Впервые в истории российской политико-правовой идеологии революционно-демократическую концепцию выдвинул $\quad$ Александр Николаевич Радищев. Он полагал, что средством перехода к республике и отмене крепостного права должно быть народное восстание ${ }^{14}$.

Радищев считал допустимым цареубийство и в оде «Вольность» призывал к вооруженной борьбе за свободу:

Возникнет рать повсюду бранна,

Надежда всех вооружит;

В крови мучителя венчанна

Омыть свой стыд уж всяк спешит.

Меч остр, я зрю, везде сверкает,

В различных видах смерть летает,

Над гордою главой царя.

Ликуйте, склепанны народы;

Се право мщенное природы

На плаху возвело царя ${ }^{15}$.

Идеи Радищева в дальнейшем получили свое развитие в проектах декабристов.

Несмотря на известные расхождения в программных вопросах, тактические взгляды Южного и Северного обществ были схожими. В качестве основного метода борьбы предлагалось вооруженное восстание военных («военная революция») под руководством членов тайного общества.

«Подготовительную работу среди войск «южане» предполагали вести в двух направлениях: во-первых, углубить недовольство и возмущение солдат существующими в армии порядками; во-вторых, завоевать к себе симпатию солдат, воспитать в солдатах слепую преданность своему командиру, чтобы

14 Учение Радищева о праве угнетаемых на восстание составило философскополитическую основу его сочинения «Житие Ф.В. Ушакова».

${ }_{15}$ См.: Радищев А.Н. Путешествие из Петербурга в Москву. Ода «Вольность». Л.: Лениздат, 1971. 
он в любой момент мог поднять воинскую часть и уверенно повести ее за собой» ${ }^{16}$. В отличие от «южан», «северяне» не вели по существу никакой работы среди нижних чинов. Один из членов Северного общества Е.П. Оболенский на допросе показал, что они «правилом положили не действовать на нижних чинов до окончательного решительного действия как для безопасности общества, так и почитая излишним открывать нижним чинам тайну» ${ }^{17}$. Основной упор был сделан на максимальное вовлечение офицеров в Северное общество и на поднятие авторитета офицеровдекабристов среди подчиненных им солдат.

Восставший народ представлялся декабристам «бунтарской» неорганизованной массой. Они были убеждены, что участие народа в революции приведет к огромным потрясениям в стране и гибели долгожданной свободы.

За тактику «народной революции», резко отличавшуюся от тактики «северян» и «южан», стояло «Общество соединенных славян». Но «соединенные славяне» составляли незначительную группу. Войдя в состав Южного общества, «соединенные славяне» приняли его программу и тактику.

Вторая половина XIX в. ознаменовалась возникновением в России народничества, родоначальниками которого были Александр Иванович

\section{Герцен и Николай Гаврилович Чернышевский}

Герцен и Чернышевский видели возможность перехода к будущему «русскому социализму» через крестьянскую общину.

Герцен считал, что социальную революцию можно осуществить как мирными (он отдавал им приоритет), так и насильственными методами.

Проблема революционного насилия была рассмотрена Герценом в статьях «К старому товарищу» (М.А. Бакунину), написанных в 1869 г.

16 См.: Анисимов И.В., Кузьлин Г.В. и др. Декабристы: Сб. статей. М: Изд-во ВПА, 1951. C. 22.

\footnotetext{
${ }^{17}$ Цит. по указ. соч. С. 31.
} 
«...Насильем можно разрушать и расчищать место - не больше. Петрограндизмом социальный переворот дальше каторжного равенства Гракха Бабефа и коммунистической барщины Кабе не пойдет... Экономический переворот имеет необъятное преимущество перед всеми религизными и политическими революциями - в трезвости своей основы» ${ }^{18}$.

Пытаясь сблизиться со славянофилами на почве общины, западник Герцен обособляет русскую повстанческую идеологию от западной: «Мы не западные люди, мы не верим, что народы не могут идти вперед иначе, как по колена в крови; мы преклоняемся с благоговением перед мучениками, но от всего сердца желаем, чтоб их не было» ${ }^{19}$.

Возможность насильственного свержения капитализма Герцен допускал как крайнюю меру: «Но к топору, к этому ultima ratio притесненных, мы звать не будем до тех пор, пока останется хоть одна разумная надежда на развязку без топора» ${ }^{20}$.

Чернышевский обосновывал невозможность реформ в современной ему России. Единственный путь решения социальных проблем он видел в народной революции, которая ограничит частную собственность и ликвидирует наемный труд. В послании «Барским крестьянам» Чернышевский призывал к крестьянскому бунту.

Под воздействием теоретических разработок «русских социалистов» сложились взгляды Петра Никитича Ткачева.

Он полагал, что социальная революция в России должна быть осуществлена немедленно, пока в стране окончательно не оформились буржуазные отношения. Подобно Бланки, Ткачев ошибочно считал, что для осуществления социалистических преобразований группе хорошо организованных революционеров-заговорщиков достаточно захватить политическую власть.

${ }^{18}$ См.: Гериен А.И. К старому товарищу / Герцен А.И. Избр. философ. произв. М., 1948. T.2. С. $300-317$.

${ }_{19}$ См.: Гериен А.И. Русские немцы и немецкие русские / Герцен А.И. Собрание сочинений в 30 т. М., 1958. Т. 14. С. 186.

${ }^{20}$ См.: Там же. Т. 14. С. 239. 
Опыт буржуазных революций 1848-1849 гг. в Европе послужил основанием для возникновения марксистской идеологии, в рамках которой следует выделить учение о социалистической революции.

Идеологическое обоснование восстания нашло свое отражение уже в ранних работах Карла Маркса и Фридриха Энгельса ${ }^{21}$. «Описывая наиболее общие фразы развития пролетариата, мы прослеживали более или менее прикрытую гражданскую войну внутри существующего общества вплоть до того пункта, когда она превращается в открытую революцию и пролетариат основывает свое господство посредством насильственного ниспровержения буржуазии» 22.

Не отрицая права на вооруженное восстание, марксисты отдавали приоритет мирному разрешению кризисов общественного развития.

«...Если социальная революция и осуществление коммунизма на практике являются необходимым следствием существующих у нас отношений, то нам прежде всего придется заняться теми мероприятиями, при помощи которых можно предотвратить насилие и кровопролитие при осуществлении переворота в социальных отношениях. А для этого имеется лишь одно средство, именно - мирное осуществление или, по крайней мере, мирная подготовка коммунизма» ${ }^{23}$.

В работе «Принципы коммунизма» (1847) Энгельс следующим образом ответил на вопрос «возможно ли уничтожение частной собственности мирным путем»: «Можно было бы пожелать, чтобы это было так, и коммунисты, конечно, были бы последними, кто стал бы против этого возражать» ${ }^{24}$.

С учетом возможности вооруженных выступлений, марксистами была разработана тактика пролетариата в буржуазной революции, которая

21 См. также: Минц И. Маркс о вооруженном восстании // Историк-марксист. 1933. № 2. C. 61-88.

22 См.: Маркс К. и Энгельс Ф. Манифест коммунистической партии // Маркс К. Избранные произведения в 2-х т. Т.1. Изд-во ЦК ВКП (б), 1934. С. 144-180.

${ }_{23}$ См.: Энгельс $\Phi$. Эльберфельдские речи. Речь 15 февраля 1845 г. // Маркс К., Энгельс Ф. Соч. 2-е изд. Т. 2. С. 554.

${ }^{24}$ См.: Энгельс Ф. Принципы коммунизма // Маркс К. и Энгельс Ф. Избранные произведения в 3-х т. Т.1. Изд-во полит. лит-ры, 1979. С. 86. 
сформулирована в «Обращении Центрального комитета к союзу коммунистов».

«...Рабочие не только не должны выступать против так называемых эксцессов, против случаев народной мести по отношению к ненавистным лицам или официальным зданиям, с которыми связаны только ненавистные воспоминания, они должны не только терпеть эти выступления, но и взять на себя руководство ими...

Наряду с новыми официальными правительствами они должны сейчас же учреждать собственные, революционные рабочие правительства, будь то в форме органов местного самоуправления, муниципальных советов, будь то через рабочие клубы или рабочие комитеты, так, чтобы буржуазнодемократические правительства не только немедленно утратили опору в рабочих, но и увидали бы себя с самого начала под наблюдением и угрозой властей, за которыми стоит вся масса рабочих.

...Оружие и боеприпасы ни под каким предлогом они не должны сдавать; всякой попытке разоружения в случае необходимости следует давать вооруженный отпор $»^{25}$.

Энгельс во введении к «Классовой борьбе во Франции с 1848 по 1850 г.» проанализировал причины успехов и неудач восстаний 1830 г. (Париж), 1848 г. (Париж, Вена, Берлин), 1849 г. (Дрезден) и разработал тактику действий повстанцев.

Он писал, что «восстание старого типа, уличная борьба с баррикадами, которая до 1848 г. повсюду в конечном счете решала дело, в значительной степени устарела... Наибольшего, чего может достичь восстание в чисто тактическом смысле, - это сооружение и защита по всем правилам искусства какой-нибудь отдельной баррикады. Взаимная поддержка, расположение и соответственно использование резервов, - словом, согласование действий и взаимодействие отдельных подразделений, необходимые даже для защиты

25 См.: Маркс $K$. и Энгельс $\Phi$. Обращение Центрального комитета к союзу коммунистов (1850) // Избранные произведения в 3-х т. Т.1. Изд-во полит. лит-ры, 1979. С. 187-188. 
какого-нибудь одного городского района, не говоря уже о защите целого большого города, - достижимы лишь в очень слабой степени, а большей частью и вовсе недостижимы; сосредоточение боевых сил в одном решающем пункте отпадает здесь само собой. Поэтому преобладающей формой борьбы является пассивная оборона: если наступление кое-где и предпринимается, то лишь в виде исключения, для случайных вылазок и фланговых атак, как правило же, наступление ограничивается лишь занятием позиций, оставленных отступающими войсками...Во всех случаях восставшие одерживали победу потому, что войска отказывались стрелять, что у командиров пропадала решительность или же потому, что у них были связаны руки» ${ }^{26}$.

Энгельс отмечал, что уличные бои серьезно изменились, и не в пользу повстанцев. Войска освоились с тактикой уличной борьбы, увеличились городские гарнизоны, модернизировалось оружие. «...И вышло так, что буржуазия и правительство стали гораздо больше бояться легальной деятельности рабочей партии, чем нелегальной, успехов на выборах, - чем успехов восстания. ... Само собой разумеется, что из-за этого наши товарищи за границей ни в коем случае не отказываются от своего права на революцию. Ведь право на революцию является единственным действительно «историческим правом» - единственным, на котором основаны все без исключения современные государства» ${ }^{27}$.

В конце 18 века в результате разочарования в способности государства регулировать социальные и экономические противоречия буржуазного общества возникает идеология анархизма.

В рамках данного исследования основное внимание уделено политикоправовым доктринам революционных анархистов (в первую очередь, Бакунина и Сореля).

${ }^{26}$ Там же. Энгельс Ф. Введение к классовой борьбе во Франции с 1848 по 1850 гг. С. 205-207. 209. 
Революционный анархизм призывал к уничтожению государства, его политико-правовых институтов и установлению идеального общественного строя, основанного на имущественном равенстве и свободном соглашении различных ассоциаций производителей.

Видным теоретиком революционного анархизма был Михаил Александрович Бакунин.

Бакунин выступал за интернациональную анархическую социальную революцию, которая уничтожит капитализм и государство. Восстание каждого народа должно происходить не с точки зрения его интересов, а с точки зрения интересов всего мира. Во всем мире должна быть одна всеобщая революция. Цель такой революции может быть сформулирована в двух словах: «политически это - отмена исторического права, права завоевания и права дипломатического. Это - полное освобождение лиц и ассоциаций от ига божественного и человеческого авторитета, полное разрушение принудительных объединений и сочетаний общин в провинции, провинций же и завоеванных стран в государстве. Это, наконец, полное, коренное упразднение централистского, опекающего, авторитарного государства со всеми его военными, бюрократическими, правительственными, административными, судебными и гражданскими установлениями. Одним словом, это - возвращение свободы всем - лицам, коллективам, ассоциациям, общинам, провинциям, областям, нациям - и взаимная гарантия этой свободы посредством федерации. С социальной же точки зрения это - подкрепление политического равенства при посредстве равенства экономического» ${ }^{28}$.

По мнению Бакунина, «анархическая революция совершается путем кровавого насилия и она предполагает, хотя и не организованную, власть взбунтовавшегося народа над личностью» ${ }^{29}$.

28 См.: Бакунин М.А. Революционный катехизис / Избранные философские сочинения и письма. М.: Мысль, 1987. С. 278.

${ }^{29}$ См.: Бердяев Н. Русская идея // Вопросы философии. 1990. № 2. С. 97-99. 
Среди революционных анархических теорий заметно выделяется теория Жоржа Сореля.

Сорель считал революционное насилие движущей силой истории и полагал, что общество нуждается в обновлении насильственным путем. Силой, способной обновить общество, является пролетариат. Насилие пролетариата, по мнению Сореля, спасет мир.

Во-первых, такое насилие позволит возродить буржуазию, что было бы тождественно подготовке экономических условий социализма. Во-вторых, насилие революционно воспитает сам пролетариат.

Несмотря на восхваление насилия, Сорель, как и другие анархосиндикалисты, не отвергает и тактику «прямого действия» (саботаж, бойкот, захват рабочими фабрик и заводов и, как высшую форму борьбы, всеобщую забастовку).

Отмечая некоторую поверхностность и иррациональность учения Жоржа Сореля, следует подчеркнуть, что он отрицал закономерный характер развития общественных противоречий, необходимых для осуществления революции. В социалистической революции он видел только спонтанный порыв народа. Вызывает сомнение и предложенная им возможность возрождения буржуазии путем насилия.

На качественно ином уровне стратегию и тактику вооруженного восстания научно обосновал Владимир Ильич Ленин.

Он развил марксистские представления о вооруженном восстании в новых исторических условиях. Ленин считал вооруженное восстание важнейшим и самым энергичным средством завоевания власти рабочим классом и полагал, что «без революционной теории не может быть и революционного движения».

Основываясь на опыте русских революций и международной революционной борьбы, Ленин выделил признаки революционной ситуации: «Лишь тогда, когда «низы» не хотят старого и когда «верхи» не могут постарому, лишь тогда революция может победить. Иначе эта истина 
выражается словами: революция невозможна без общенационального кризиса» ${ }^{30}$.

В статье «Марксизм и восстание» Ленин писал: «Восстание, чтобы быть успешным, должно опираться не на заговор, не на партию, а на передовой класс. Это во-первых. Восстание должно опираться на революционный подъем народа. Это во-вторых. Восстание должно опираться на такой переломный пункт в истории нарастающей революции, когда активность передовых рядов народа наибольшая, когда всего сильнее колебания в рядах врагов и в рядах слабых половинчатых нерешительных друзей революции. Это в-третьих. Вот этими тремя условиями постановки вопроса о восстании и отличается марксизм от бланкизма» ${ }^{31}$.

Ленин призвал относиться к восстанию, как к искусству: «...отказаться от отношения к восстанию, как к искусству, значит изменить марксизму и изменить революции» ${ }^{32}$.

Ленин выдвинул тезис о решающем значении для победы революции союза пролетариата и крестьянства: «Победа может быть достигнута лишь при том условии, если пролетариату удастся повести за собой большую часть крестьянства» ${ }^{33}$.

Важной ступенью в разработке Лениным плана Октябрьского вооруженного восстания стала статья «Советы постороннего» ${ }^{34}$. В ней были сформулированы следующие правила восстания:

«1) Никогда не играть с восстанием, а, начиная его, знать твердо, что надо идти до конца.

30 См.: Ленин В.И. Полное Собрание сочинений. Т. 41, С. 69-70. Октябрьское вооруженное восстание стало возможным осенью 1917 г. благодаря общенациональному кризису в России. Широкий размах приняло стачечное движение, развернулась борьба крестьян против помещиков. Происходила большевизация Советов и армии. Глубокий экономический кризис совпал с политическим кризисом Временного правительства. Все это и привело к революционной ситуации.

${ }^{31}$ См.: Там же. Т. 34, С. 242-243.

32 Там же.

33 Там же. Т. 15, C. 332.

34 Перечисленные в статье правила восстания заимствованы Лениным у Энгельса. См.: Энгельс Ф. Революция и контрреволюция в Германии / Маркс К. и Энгельс Ф. 2-е изд. Соч. М., 1955-1973. Т.8. С. 100. 
2) Необходимо собрать большой перевес сил в решающем месте, в решающий момент, ибо иначе неприятель, обладающий лучшей подготовкой и организацией, уничтожит повстанцев ${ }^{35}$.

3) Раз восстание начато, надо действовать с величайшей решительностью и непременно, безусловно переходить в наступление. «Оборона есть смерть вооруженного восстания».

4) Надо стараться захватить врасплох неприятеля, уловить момент, пока его войска разбросаны.

5) Надо добиваться ежедневно хоть маленьких успехов (можно сказать: ежечасно, если дело идет об одном городе), поддерживая, во что бы то ни стало, «моральный перевес» ${ }^{36}$.

В работе «Большевики должны взять власть» Ленин подчеркивал необходимость решительного наступления во время восстания в главных центрах страны $^{37}$. Важное значение придавал организации и военнотехнической подготовке вооруженным восстанием. Руководство восстанием должно быть возложено на пролетарскую партию, действующую не «заговорщически», а в тесной связке с народом.

Ленин особое внимание обращает на то, что рабочий класс, борясь за власть, должен уничтожить старую, буржуазную государственную машину и создать новое, пролетарское государство.

В отличие от марксистского положения о том, что социалистическая революция может победить лишь одновременно во всех развитых капиталистических странах, Ленин в работах «О лозунге Соединенные Штаты Европы» (1915) и «Военная программа пролетарской революции» (1916) сделал вывод о возможности победы социалистической революции в нескольких или в одной, отдельно взятой стране.

35 Применительно к Октябрьскому вооруженному восстанию это означало скопление перевеса сил флота, рабочих и войска над юнкерами и казачеством, и окружение Петрограда.

${ }^{36}$ Там же. Т. 34. С. 383-384.

37 «Взяв власть сразу и в Москве и в Питере, - указывал Ленин, - мы победим безусловно и несомненно». См.: Ленин В.И. Полное Собрание сочинений. Т. 34, С. 241. 
Теоретические взгляды Ленина и его практическая деятельность оказали решающее воздействие на развитие советской идеологии, правопонимания и государствоведения.

В советский период в марксистско-ленинской теории государства и права право на восстание рассматривалось через соотношение социалистической революции и права.

Как отмечалось, «не следует смешивать право трудящегося народа на революцию или право наций на самоопределение с правом как особым юридическим феноменом. Право трудящихся на революцию против эксплуататоров, на революционное преобразование мира (право не в смысле системы юридических норм, а более глубокое социальное явление) объективная необходимость и социальная оправданность политики рабочего класса, всех трудящихся» ${ }^{38}$.

Обоснование права на восстание использовалось в качестве фундамента идеологии пролетарского интернационализма. «Интернационализм на деле,указывал Ленин, - один и только один: беззаветная работа над развитием революционного движения и революционной борьбы в своей стране, поддержка такой же борьбы, такой же линии, и только ее одной во всех без исключения странах $»^{39}$.

Отказ от однопартийной политической системы, курс на гласность, «новое политическое мышление» и демократизацию общественной жизни в Советском Союзе вызвали критику господствующей марксистско-ленинской идеологии и возникновение альтернативных политико-правовых доктрин. Последовавший затем распад СССР и социалистического лагеря, ликвидация советской власти и ориентация нового руководства России на политику стран «западной демократии» привели к постепенному отказу от идей

${ }^{38}$ См.: Проблемы теории государства и права: Учебник / Под ред. С.С. Алексеева. М.: Юрид. лит., 1979. С. 266.

39 См.: Ленин В.И. Полное Собрание сочинений. Т. 31, С. 170. Цитируемые положения идеологически обосновывали поддержку Советским Союзом коммунистических партий в различных странах мира, a также международного революционного движения. 
социалистической революции и поддержки Советским Союзом революционного движения в различных регионах мира.

В новых исторических условиях сфера применимости политических методов и средств, основанных на насилии, оказалась довольно узкой.

Такова общая характеристика формирования и развития основных политико-правовых, религиозных и философских идей и взглядов, обосновывающих право народа на восстание.

Анализ исторического опыта идеологии восстания позволяет выделить некоторые теоретические установки, нашедшие подтверждение в политической практике:

а) При разрешении существующих в обществе острых противоречий предпочтение следует отдавать установленным законом (легальным) способам разрешения социальных конфликтов;

б) Идеология восстания эффективна там и тогда, где и когда существует острое недовольство населения государственно-политическим режимом, своим социально-экономическим положением, господствующей идеологией, и когда в само революционное движение вовлечена подавляющая часть населения государства.

в) Идеология восстания становится господствующей в том обществе, в котором закономерно назрели предпосылки формирования нового общественного строя.

г) Важное значение имеют организация и военно-техническая подготовка вооруженного восстания. Партия, осуществляющая руководство восстанием, должна иметь разветвленную систему своих органов по всей стране, опираться на единомышленников по взглядам, но при этом не быть сектантской, «заговорщической».

д) Восстание должно носить наступательный характер.

Рассмотрев в общих чертах эволюцию основных идей и взглядов, составляющих идеологию восстания, необходимо проанализировать современную ее трактовку. 
Сегодня идеология восстания и ее положительная роль в общественном развитии оценивается не столь однозначно.

Во-первых, право на восстание в современных условиях во многом утратило свою актуальность. Всеобщее избирательное право, активная деятельность политических партий и профсоюзов, рост благосостояния населения повлекли за собой необходимость более широкого использования правовых механизмов регулирования возникающих социальных противоречий. Снижение интереса к идеологии восстания также связано с разработкой ненасильственных методов сопротивления и практической неспособностью повстанцев длительное время оказывать сопротивление современным вооруженным силам и подразделениям специального назначения.

Во-вторых, в настоящее время право на восстание практически исчезло из каких-либо политических документов и правовых актов. Как справедливо отмечает Сырых В.М., - «Всеобщая декларация прав и свобод человека, иные акты международного права весьма глухо говорят о праве гражданского общества на восстание против тиранического, авторитарного государства. Действующие конституции правовых государств и вовсе умалчивают об этом праве» ${ }^{40}$.

B-третьих, право на восстание в настоящее время противоречит действующему законодательству. Конституционное и уголовное законодательство большинства государств запрещает насильственное изменение конституционного строя. Такая позиция продиктована стремлением обеспечить стабильность конституционного строя, не допустить нарушений законности и человеческих жертв. Иначе как разграничить народное восстание и экстремистскую деятельность, восстание и вооруженный мятеж, восстание и массовые беспорядки и т.п.?

Как правило, политическая оппозиция проводит свои акции под лозунгами отсутствия у правящего режима поддержки населения и

40 Там же. Необходимо все же отметить, что в Основном Законе ФРГ закреплено право на сопротивление тому, кто пытается устранить государственный строй Германии. 
требованиями мирной передачи власти ${ }^{41}$. Но кто может гарантировать, что очередная «бархатная», «хлопковая», «оранжевая» и т.п. революция не обернется кровавой резней, погромами и бандитизмом, как в Киргизии? Наконец, даже если бы право на восстание было нормативно закреплено, оно стало бы противоречить законодательству о чрезвычайном положении, которое вводится в подобных случаях.

Нецелесообразность нормативного закрепления права на восстание обусловлена и реальной возможностью отдельных иностранных государств использовать положения национального законодательства той или иной страны для решения собственных политических и экономических задач. Представьте, что будет, если в конституционной практике начнется использование права на восстание, как сейчас США и страны «западной демократии» используют избирательное право (финансирование кандидатов и общественных организаций политической направленности, институт международных наблюдателей, СМИ) для вмешательства во внутренние дела иностранных государств и продвижения своих ставленников на выборные должности. Закрепить в конституционном законодательстве подобное положение означает заложить бомбу замедленного действия.

Право на восстание - это крайнее средство. Право на восстание можно сравнить с правом на использование ядерного оружия. И то, и другое право можно использовать только для защиты жизней миллионов граждан, когда все иные возможности исчерпаны (например, вполне допустимым являлось бы использование права на восстание в условиях режима Пола Пота и уничтожения миллионов граждан Кампучии или для освобождения от фашистской оккупации).

В современных условиях практическая реализация права народа на восстание может быть связана только со следующими обстоятельствами:

проведение государственными органами и должностными лицами политических репрессий или политики геноцида населения, а также в случае

41 Данная практика оправдывает себя, о чем свидетельствует падение режимов Э. Шеварднадзе в Грузии, Р.Абашидзе в Аджарии, «оранжевая» революция в Украине. 
захвата государства или части его территории другим государством (военнополитическим блоком государств).

Политические репрессии означают применение насилия и террора для подавления политических противников и любых форм инакомыслия. Карательная политика и произвол государства по отношению к собственным гражданам автоматически освобождают этих людей от лояльности применяющему репрессии политическому режиму. Уничтожение неповинных людей и концентрационные лагеря никогда и ничем нельзя оправдать.

Под геноцидом населения нужно понимать уничтожение этнических, расовых или религиозных групп населения, причинение тяжкого вреда их здоровью (т.н. «этнические чистки»), насильственное противозаконное перемещение людей (депортацию), а также создание таких социальноэкономических условий, которые приводят к физическому вымиранию населения. Осуществление вооруженного восстания против государства, выступающего в роли преступника по отношению к целым народам, будет ничем иным, как необходимой обороной.

Вооруженное вторжение и захват территории государства, произведенные без санкций международных организаций (Совета Безопасности ООН), нарушают нормы международного права и являются безусловным правомерным основанием для сопротивления агрессорам и ликвидации установленных ими конституции, формы правления и политического режима ${ }^{42}$. Никакое иностранное государство (блок государств) не правомочно ликвидировать и устанавливать ту или иную форму другого государства, в том числе под предлогом защиты прав человека и свержения тоталитарного режима. Такая прерогатива принадлежит только народу этого государства. Поэтому защищать свое

42 Как свидетельствует исторический опыт XX века, вооруженное восстание остается важным средством борьбы с оккупантами. Примерами могут служить Парижское восстание (19-25 августа 1944 г.), народное восстание в Северной Италии (25 апреля 1945 г.), Пражское восстание (май 1945), в ходе которых были свергнуты оккупационные власти и освобождены захваченные нацистами территории. 
Отечество от вторжения захватчиков и участвовать в восстановлении государственного суверенитета должен, по мере возможности, каждый гражданин.

В других обстоятельствах практическая реализация права на восстание не допустима: должны проходить предусмотренные законодательством массовые общественно-политические акции (забастовки, пикетирования, демонстрации и т.д.), а также использоваться возможности выборного процесса (переизбрание должностных лиц и депутатов) и право отзыва ${ }^{43}$.

В заключение отметим, что в современных условиях право народа на восстание и его идейное оформление выступают уже не в качестве действенных инструментов прогрессивного преобразования общественных отношений (кроме упомянутых исключений), а скорее как идеологические гарантии членам общества против произвола государственной власти. Руководители государства и представители органов власти различного уровня вынуждены считаться с возможностью сопротивления населения законам и политическим решениям, нарушающим их права и интересы. Опыт истории свидетельствует, что принцип «после нас - хоть потоп» лучше не использовать в политической практике, которая может быть в этом случае неожиданно принудительно завершена.

Источник опубликования: Красинский В.В. Идеология восстания в истории политико-правовых учений // Политика и общество. 2005. № 6. С. $19-29$.

${ }^{43}$ Понятно, что если государственное руководство проводит политику геноцида или массовых репрессий в отношении населения, то через несколько лет против таких политических деятелей будет просто некому голосовать и бастовать. 